\title{
ANALISIS KEBERHASILAN PROGRAM PENDAMPINGAN PENGEMBANGAN PRODUK UMM BAKERY METODE FROZEN DAN SOURDOUGH SEBAGAI UPAYA MENINGKATKAN UMUR SIMPAN DAN EFISIENSI PRODUKSI ROTI DI UMM BAKERY
}

\author{
${ }^{1)}$ Desiana Nuriza Putri, ${ }^{2)}$ Livia Windiana dan ${ }^{3)}$ Nadia Mardhiyah \\ Fakultas Pertanian dan Peternakan, Universitas Muhammadiyah Malang \\ Jl. Raya Tlogomas 246 Malang, Jawa Timur, Indonesia \\ Email: ${ }^{1)}$ dndesiana.nuriza@gmail.com, ${ }^{2)}$ windianalivia@yahoo.co.id, \\ ${ }^{3)}$ mardhiyah.nadia@gmail.com
}

\begin{abstract}
ABSTRAK
The development of the era changed the lifestyle and tastes of people to food, one of which bread that has now become food processed that often consumed by society. Increasing public interest in the consumption of bread leads to increased interest in business in the field of bakery. UMM Bakery as one of the business units in the field of bread and cake production commits the manufacture of its products do not use chemical preservatives. The use of chemical preservatives is what causes UMM Bakery products have a shelf life that is not long. Abundant orders also cause a lack of efficiency of human resources due to the swelling of the production costs of the cost of energy added. UMM Bakery Product Development Program in the form of dough making type sourdough and Frozendough become the right alternative to be applied. Sourdough can be a solution to overcome the use of commercial yeast into natural yeast that can later increase the shelf life and create a distinctive flavor of the product. Frozen dough method is also appropriately applied to increase energy efficiency in bread production to avoid swelling of production costs and maintain the quality of the product remains good.
\end{abstract}

Keywords: bakery, sourdough, frozendough, umur simpan, efisiensi produksi

\section{PENDAHULUAN}

Seiring dengan perkembangan zaman, terjadi perubahan gaya hidup dan selera masyarakat terhadap makanan. Salah satu makanan olahan yang biasa dikonsumsi masyarakat adalah roti. Sebagian besar roti yang beredar di Indonesia adalah roti yang terbuat dari yeast komersial. Pemakaian yeast komersial dapat mengempukkan roti secara cepat namun roti yang dihasilkan memiliki flavor kurang enak, bertekstur lembek dan umur simpan yang pendek. Produsen roti di Indonesia banyak yang menambahkan bahan pengawet kimia untuk memperpanjang umur simpan roti. Bahan pengawet kimia yang digunakan ini bisa memberikan dampak yang kurang baik jika dikonsumsi secara berkelanjutan.

Bakery sebagai unit usaha dalam bidang pangan yang kini banyak ditemui di pasaran. Mulai dari kisaran harga rendah hingga tinggi, dari varian manis hingga yang asin, sampai berbagai macam bentuk roti dan olahan tepung lainnya disuguhkan pada bakery yang kini bersaing dengan tren yang terus terbarukan. Menyikapi setiap perbaruan yang ada, bakery seolah diwajibkan memiliki sesuatu yang khas untuk bisa bertahan di tengah derasnya arus tren olahan pangan. Oleh sebab itu, sesuatu yang khas dari mulai adonan maupun varian yang ada harus bisa menyuguhkan manfaat bagi konsumen selain dari segi tampilan maupun harganya. Tak hanya kepada konsumen, pertimbangan perihal 
Desiana Nuriza Putri, Livia Windiana \& Nadia Mardhiyah 2019. Analisis Keberhasilan Program

Pendampingan Pengembangan Produk Umm Bakery Metode Frozen dan Sourdough Sebagai

Upaya Meningkatkan Umur Simpan dan Efisiensi Produksi Roti di UMM Bakery Journal Viabel Pertanian. (2019), 13(2)1-10

biaya produksi dan kefektifan Sumber Daya Manusia (SDM) yang ada juga harus menjadi poin penting dalam bergeraknya unit usaha bakery.

UMM bakery adalah unit usaha Universitas Muhammadiyah Malang yang bergerak di bidangbakery dan cake. Adanya unit usaha ini memiliki manfaat yang bisa dirasakan jug aoleh mahasiswa, yakni adanya kesempatan pembelajaran yang bisa didapatkan langsung dari bakery selain dari bangku perkuliahan. Saat ini UMM bakery telah berkembang dan memiliki beberapa varian roti dari adonan yang menggunakan ragi komersial dan metode konvensinal. Produk UMM Bakery sering menjadi suguhan dan bingkisan pada kegiatan-kegiatan yang diadakan oleh Universitas Muhammadiyah Malang, dari mulai tingkat jurusan atau program studi hingga pada tingkat universitas dan kegiatan nasional yang diadakan. Varian yang banyak dan harga yang bervariasi juga bisa menjadi hal yang efektif untuk menjadi pertimbangan pemilik kegiatan untuk memilih UMM Bakery sebagai brand konsumsi yang disuguhkan.

Terdapat dua permasalahan penting pada usaha UMM Bakery yaitu, umur simpan roti yang rendah dan efisiensi tenaga produksi yang kecil saat menerima pesanan dalam jumlah yang besar. Permasalahan pertama adalah umur simpan roti yang rendah, karena UMM bakery tidak menggunakan bahan kimia sebagai pengawet, maka perlu suatu metode untuk meningkatkan umur simpan. Permasalahan kedua yakni Sumber Daya Manusia (SDM) ketika kapasitas produksi meningkat seperti ada pesanan dalam jumlah ribuan. Hal ini dikarenakan setiap ada pesanan dalam jumlah besar, mitra mencari tenaga lembur untuk membantu proses produksi yang berakibat biaya produksi meningkat. Permasalahan ini dapat diatasi melalui penerapan pembaruan metode pada adonan yang digunakan, diantaranya adalah sourdough dan frozendough.

Jenis adonan berupa sourdough, belum sering terdengar di kalangan masyarakat umum. Perbedaan yang ada pada sourdough dan adonan lain adalah dari segi pemakaian ragi. Jika dalam adonan biasa menggunakan ragi komersial, pada adonan sourdough menggunakan ragi alami. Sourdough adalah campuran tepung dan air yang terasa asam atau tajam untuk membuat roti dari tepung sereal (Stauffer, 1991). Roti Sourdough merupakan teknik pembuatan roti secara tradisional yang telah lama digunakan sejak jaman Mesir kuno atau sekitar 1.500 tahun SM (Moroni et al. 2009). Secara tradisional sourdough dibuat dengan cara fermentasi spontan dengan hanya mengaktifkan mikroba alami dalam biji-bijian yang telah digiling (Poutane dan Katina, 2007). Hasil penelitian Edema et al. (2008) menunjukkan bahwa pembuatan roti dengan menggunakan sourdough dapat meningkatkan kualitas roti yang dihasilkan, serta direkomendasikan sebagai metode yang efisien untuk mengurangi toksisitas dari tepung terigu. Roti yang terbuat dari sourdough memiliki rasa yang enak dan khas, tekstur lembut dan elastis, serta umur simpan yang panjang.

Selain dari segi pemakaian ragi, penerapan metode pada pembuatan adonan juga bisa menjadi efektif mengingat jumlah SDM yang kurang saat mengerjakan pesanan roti sedang tinggi. Frozendough atau adonan beku menjadi alternatif yang tepat diterapkan di UMM Bakery. Frozendough adalah adonan beku tanpa dipanggang atau baked-off adalah adonan yang telah dicampur (mixing), dibagi (dividing), dan dicetak (moulding) kemudian dibekukan (freezing). Adonan beku tersebut harus dicairkan (thawing), difermentasi lanjut (proofing) dan dipanggang (baking) sebelum dikonsumsi (Kulp, 1995 dalam Miller, 2006). Menurut Yi dan William (2009), jika dibandingkan dengan pembuatan roti konvensional, adonan beku lebih bernilai ekonomis dalam industri bakery. Pembuatan roti konvensional umumnya membutuhkan waktu yang lebih lama dan tenaga kerja ahli serta peralatan yang spesial, sedangkan adonan beku dapat 
diproduksi secara sentralisasi. Produksi secara sentralisasi, dapat membuat kualitas roti manis menjadi terstandarisasi. Selain itu, produk adonan beku dapat dibuat menjadi "fresh bread" setiap waktu apabila dibutuhkan.

Berdasarkan kondisi permasalahan pada UMM Bakery tersebut, Program Pendampingan Pengembangan UMM Bakery sangatlah diharapkan guna memperpanjang masa simpan roti dan meningkatkan efisiensi produksi pada SDM yang ada. Program Pendampingan Pengembangan UMM Bakery juga dapat meningkatkan pengetahuan karyawan terhadap teknologi pembuatan roti tercermin pada tingkat pemahaman dan ketertarikan terhadap metode frozen dan sourdough dan sebagian karyawan telah mampu mengaplikasikan teknologi ini. Ketika pesanan melonjak, hal ini bisa diatasi dengan efisien oleh adonan dan metode yang tepat untuk menjaga kualitas produksi.

\section{METODE}

Metode pemecahan masalah yang digunakan adalah metode ceramah, tanya jawab, diskusi, demontrasi, pelatihan pembuatan roti metode sourdough dan frozendough serta monitoring hasil produksi.

1. Metode ceramah

Metode ceramah dilakukan dengan tujuan menyamakan visi-misi dan sosialisasi metode pembuatan roti sehingga karyawan mengetahui dan memahami bahwa ada metode pembuatan roti yang lebih efisien untuk diaplikasikan dalam skala besar.

2. Pelatihan pembuatan roti dengan metode Frozendough

Tahapan pelatihan adalah sebagai berikut :

a. Pemberian bantuan teknologi refrigerator untuk pembuatan roti metode frozen

b. Pelatihan pembuatan roti metode frozendough

c. Pelatihan monitoring suhu pembekuan dan suhu thawing

d. Pelatihan pengecekan kualitas roti

3. Pelatihan pembuatan roti dengan metode Sourdough

a. Pengenalan metode pembuatan beserta alat dan bahan.

b. Pelatihan pembuatan ragi alami

c. Pelatihan penentuan lama fermentasi ragi alami

d. Pelatihan pembuatan roti metode sourdough

4. Evaluasi Pelaksanaan Program

Evaluasi dilakukan secara keseluruhan untuk mengetahui tingkat keberhasilan program pengabdian melalui monitoring kegiatan pelaksanaan dan pendampingan, penjadwalan waktu pengabdian, serta memastikan semua proses dan tahapan pengabdian sesuai dengan mekanisme yang telah ditentukan. Pengambilan data evaluasi menggunakan skala likert. Menurut (Hendri, 2009) skala likert merupakan teknik self report bagi pengukuran sikap dimana subjek diminta untuk mengindikasikan tingkat kesetujuan atau ketidaksetujuan mereka terhadap masing- masing pernyataan.

Evaluasi ini berdasarkan pada beberapa daftar pertanyaan yang bersifat positif dan negatif yang terdapat dalam kuisioner. Kuisioner ini diberikan kepada responden sebelum dan sesudah dilakukannya Program Pengabdian. Analisis ini didukung oleh penilaian berdasarkan pendapat responden yaitu karyawan UMM Bakery. Pengukuran dilakukan sesuai skala likert dimana setiap pertanyaan diberi skor sesuai dengan item jawaban yang dipilih dan masing- masing jawaban memiliki bobot penilaian jawaban yang berbeda berdasarkan skala likert yang dipergunakan. Berikut pembobotan setiap jawaban : Sangat setuju (bobot:
$5)$,
Setuju (bobot
:4), Netral (bobot :3), Tidak Setuju (bobot
:2), 
Copyright@UNISBA Blitar , http://ejournal.unisbablitar.ac.id/index.php/viabel

Desiana Nuriza Putri, Livia Windiana \& Nadia Mardhiyah 2019. Analisis Keberhasilan Program

Pendampingan Pengembangan Produk Umm Bakery Metode Frozen dan Sourdough Sebagai

Upaya Meningkatkan Umur Simpan dan Efisiensi Produksi Roti di UMM Bakery Journal Viabel Pertanian. (2019), 13(2)1-10

\section{Sangat tidak setuju, (bobot: 1)}

Data hasil kuisioner yang dijawab responden, diolah dengan membuat tabel pengukuran dari setiap pertanyaan yang menggunakan skala likert. Contoh tabel pengukuran dalam skala likert dapat dilihat pada Tabel 1. Berikut rumus pengukuran yaitu.

Tabel 1. Pengukuran Nilai Indeks Pada Masing-Masing Pertanyaan dengan Skala Likert

\begin{tabular}{|l|c|c|c|c|c|}
\hline Pertanyaan & $\begin{array}{c}\text { Skor Masing- } \\
\text { Masing Skala }\end{array}$ & Total Skor & $\begin{array}{c}\text { Skor } \\
\text { Maksi } \\
\text { mum }\end{array}$ & $\begin{array}{c}\text { Skor } \\
\text { Mini } \\
\text { mum }\end{array}$ & Nilai Indeks \\
\hline $\begin{array}{l}\text { Pertanyaan 1 } \\
\text { hingga 12 }\end{array}$ & $\mathrm{S}=\mathrm{T}$ x Pn & $\begin{array}{c}\mathrm{TS}=\mathrm{S}_{1}+\mathrm{S}_{2} \\
+\mathrm{S}_{3}+\mathrm{S}_{4}+\mathrm{S}_{5}\end{array}$ & $\mathrm{Y}$ & $\mathrm{X}$ & $\begin{array}{l}\text { Rumus Indeks } \\
(\%)=\mathrm{TS} /(\mathrm{Y} x \\
100)\end{array}$ \\
\hline
\end{tabular}

Keterangan :

$$
\begin{aligned}
& \mathrm{S}=\text { Skor Masing-Masing Skala } \\
& \mathrm{T} \quad=\text { Total jumlah responden yang memilih } \\
& \text { Pn } \quad=\text { Pilihan angka skor Likert } \\
& \text { TS } \quad=\text { Total Skor (Hasil penjumlahan masing-masing skor pada skala } \\
& \text { Likert) } \\
& \mathrm{S}_{1}, \mathrm{~S}_{2}, \ldots \ldots . ., \mathrm{S}_{5}=\text { Skor masing-masing skala Likert } \\
& \mathrm{Y}=\text { skor tertinggi Likert } \mathrm{x} \text { jumlah responden } \\
& \mathrm{X}=\text { skor terendah Likert } \mathrm{x} \text { jumlah responden }
\end{aligned}
$$

Setelah dilakukan analisis nilai indeks, maka selanjutnya yaitu mencari interval (rentang jarak) dan interpretasi persen untuk mengetahui keterangan hasil nilai indeks. Tabel 2. Prosentase nilai

\begin{tabular}{|c|c|}
\hline JAWABAN & KETERANGAN \\
\hline $0 \%-19.99 \%$ & SANGAT TIDAK SETUJU \\
\hline $20 \%-39.99 \%$ & TIDAK SETUJU \\
\hline $40 \%-59.99 \%$ & NETRAL \\
\hline $60 \%-79.99 \%$ & SETUJU \\
\hline $80 \%-100 \%$ & SANGAT SETUJU \\
\hline
\end{tabular}

\section{HASIL DAN PEMBAHASAN}

\section{Sosisalisasi Metode Frozen dan Metode Sourdough kepada karyawan UMM Bakery}

Sosialisasi dilakukan kepada karyawan UMM Bakery tentang definisi metode frozen dan metode sourdough, bahan dan alat yang dibutuhkan untuk pembuatan roti metode ini, perbedaan metode ini dengan metode sebelumnya serta penyampaian titik kritis atau tahap yang menentukan keberhasilan pembuatan roti menggunakan metode ini, sosialisasi dilaksanakan di pabrik roti UMM Bakery yang berada di FPP Farm. Karyawan yang mengikuti sosialisasi kurang lebih 9 karyawan. 
Desiana Nuriza Putri, Livia Windiana \& Nadia Mardhiyah 2019. Analisis Keberhasilan Program Pendampingan Pengembangan Produk Umm Bakery Metode Frozen dan Sourdough Sebagai Upaya Meningkatkan Umur Simpan dan Efisiensi Produksi Roti di UMM Bakery Journal Viabel Pertanian. (2019), 13(2)1-10
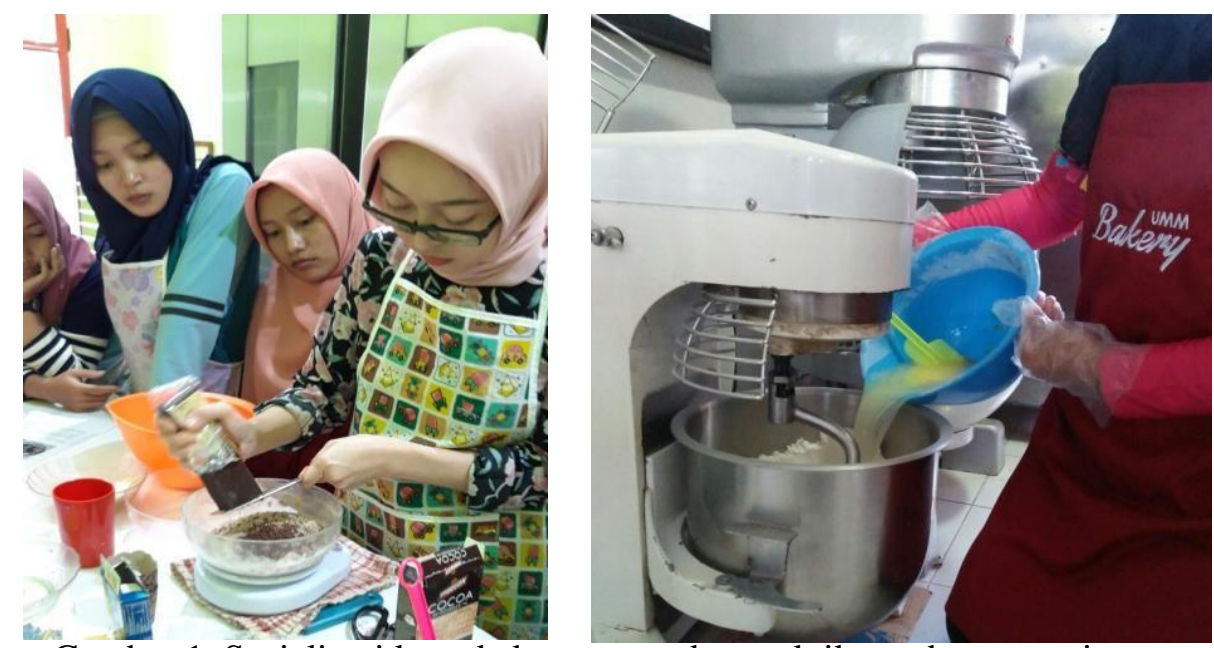

Gambar 1. Sosialisasi kepada karya wan dan praktik pembuatan roti

\section{Pelatihan pembuatan roti}

Pelatihan dilakukan dengan cara :

a. Memberikan bantuan teknologi berupa AC, showcase (refrigerator) dan bahan untuk metode frozen dan metode sourdough.

b. Melakukan pelatihan pembuatan roti menggunakan metode frozen dan metode sourdough yang dimulai dari penyampaian bahan dan alat hingga penentuan kualitas produk.
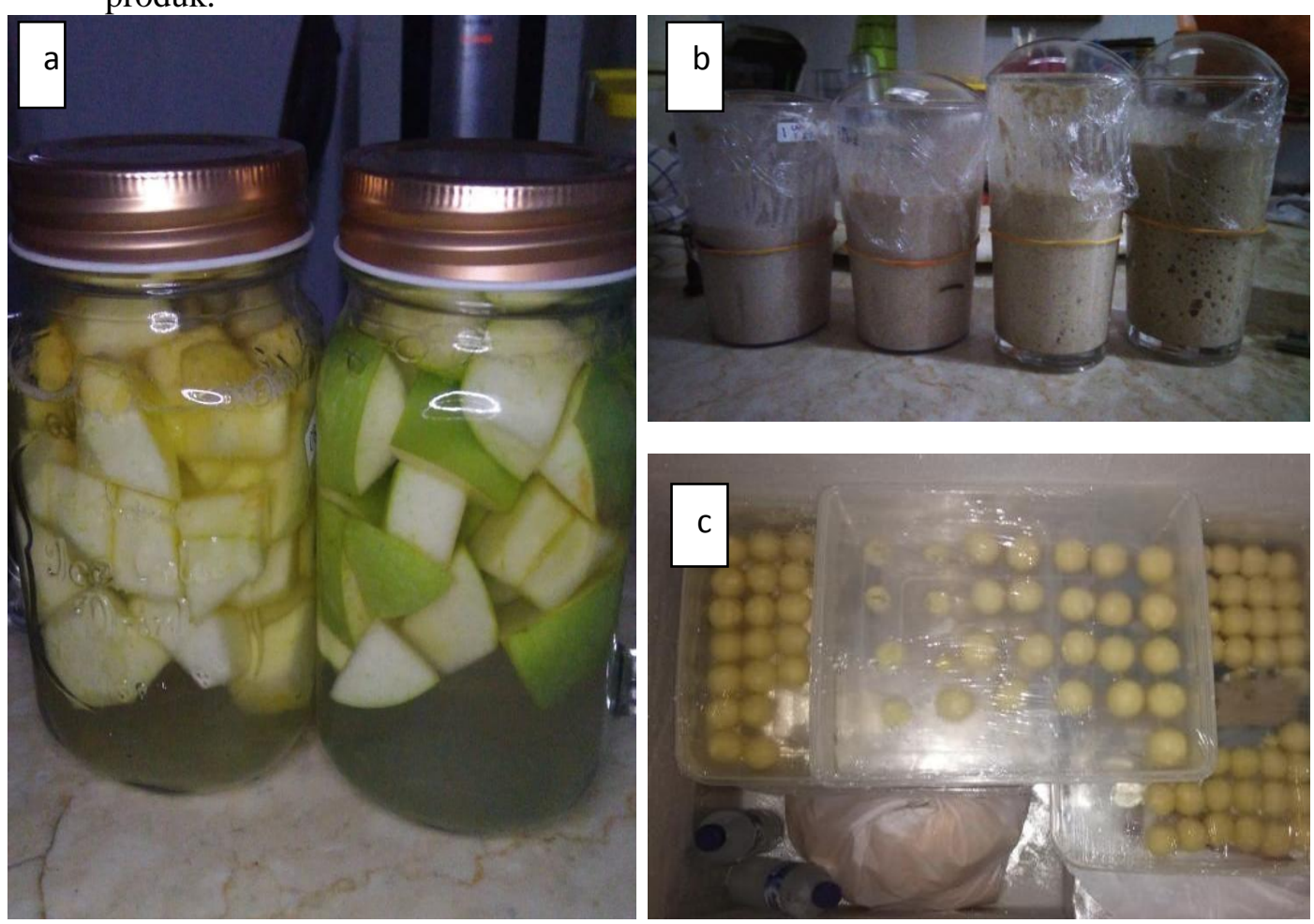

Gambar 2. a. Pembuatan ragi alami untuk sourdough b. Sourdough c. Pembekuan adonan metode frozendough 
Copyright@UNISBA Blitar, http://ejournal.unisbablitar.ac.id/index.php/viabel

Desiana Nuriza Putri, Livia Windiana \& Nadia Mardhiyah 2019. Analisis Keberhasilan Program

Pendampingan Pengembangan Produk Umm Bakery Metode Frozen dan Sourdough Sebagai

Upaya Meningkatkan Umur Simpan dan Efisiensi Produksi Roti di UMM Bakery Journal Viabel Pertanian. (2019), 13(2)1-10

\section{Proses Pembuatan Roti Manis Metode Frozen Dough}

Proses pembuatan roti manis diawali dengan mencampurkan beberapa bahan antara lain tepung terigu, ragi, gula, telur, dan air kemudian diaduk dengan dough mixer dengan kecepatan rendah selama

\pm 10 menit, kemudian sisa bahan (garam dan mmentega) dimasukkan dan diaduk dengan kecepatan tinggi selama \pm 20 menit atau sampai menjadi kalis. Kemudian adonan diistirahatkan (proofing) pada suhu $25^{\circ} \mathrm{C}$ selama 15 menit kemudian dilanjutkan pembuangan gas dari hasil fermentasi (degassing) dengan cara ditekan menggunakan penggilas atau roller. Setelah itu, adonan dibagi/dipotong rata dengan berat 50 gram (dividing), lalu dibulat-bulatkan (moulding) dan diistirahatkan selama 10 menit (intermediate proofing)di atas meja.

Adonan yang telah diistirahatkan tersebut dimasukkan ke dalam plastik polyprophylene dan dilanjutkan proses pembekuan cepat dengan suhu $-30^{\circ} \mathrm{C}$ menggunakan chest freezer selama 10 menit. Kemudian dilanjutkan penyimpanan beku dengan suhu $-15^{\circ} \mathrm{C}$ selama 7 hari. Setelah penyimpanan selama 7 hari, adonan beku dilanjutkan dengan proses thawing menggunakan inkubator dengan suhu $30^{\circ} \mathrm{C}$ selama 60 menit. Setelah proses thawing selesai, adonan dilanjutkan fermentasi akhir (final proofing) menggunakan mesin proofer dengan suhu $40^{\circ} \mathrm{C}$ selama 60 menit dengan kelembaban relatif (RH) $80-85 \%$. Selanjutnya, adonan dioven pada suhu $180^{\circ} \mathrm{C}$ selama \pm 20 menit sampai warna roti manis menjadi kuning kecoklatan. 
Copyright@UNISBA Blitar , http://ejournal.unisbablitar.ac.id/index.php/viabel

Desiana Nuriza Putri, Livia Windiana \& Nadia Mardhiyah 2019. Analisis Keberhasilan Program

Pendampingan Pengembangan Produk Umm Bakery Metode Frozen dan Sourdough Sebagai Upaya Meningkatkan Umur Simpan dan Efisiensi Produksi Roti di UMM Bakery Journal Viabel Pertanian. (2019), 13(2)1-10

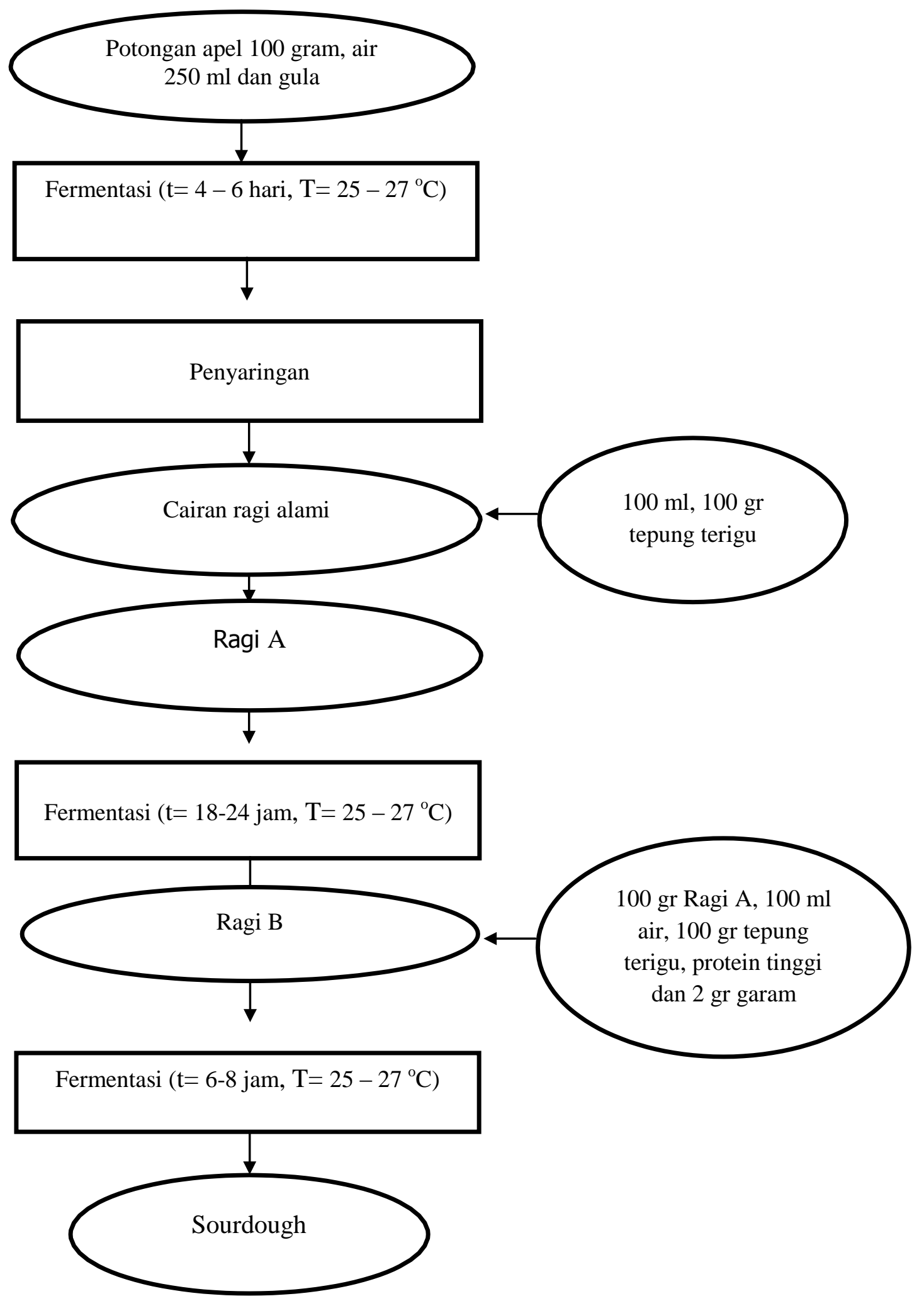

Gambar 1. Diagram Alir Proses Pembuatan sourdough dari apel (Sangjin Ko, 2012) 
Desiana Nuriza Putri, Livia Windiana \& Nadia Mardhiyah 2019. Analisis Keberhasilan Program Pendampingan Pengembangan Produk Umm Bakery Metode Frozen dan Sourdough Sebagai Upaya Meningkatkan Umur Simpan dan Efisiensi Produksi Roti di UMM Bakery Journal Viabel Pertanian. (2019), 13(2)1-10

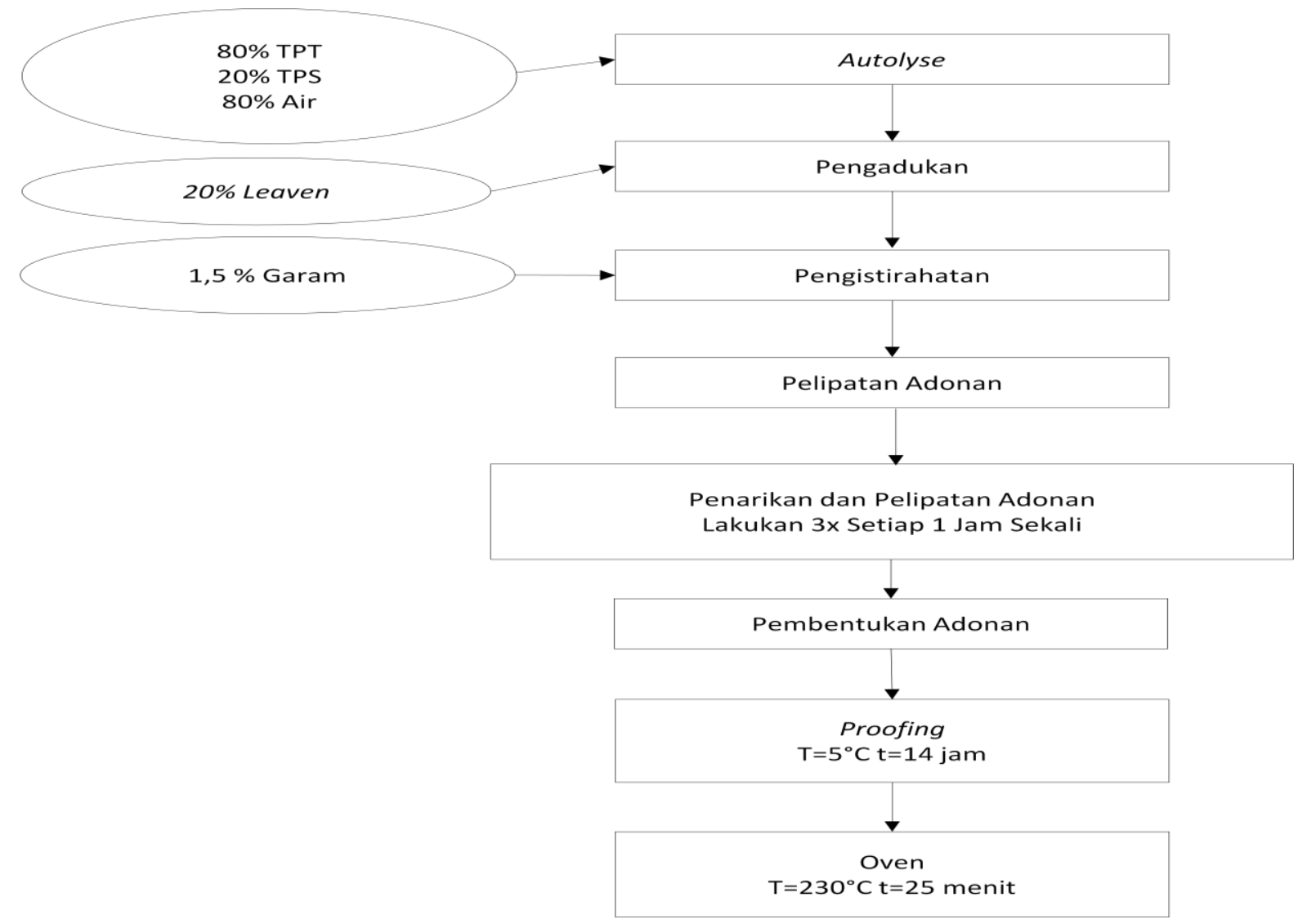

Gambar 2. Diagram Alir Proses Pembuatan Manis dari Sourdough (Umm Bakery dengan modifikasi)
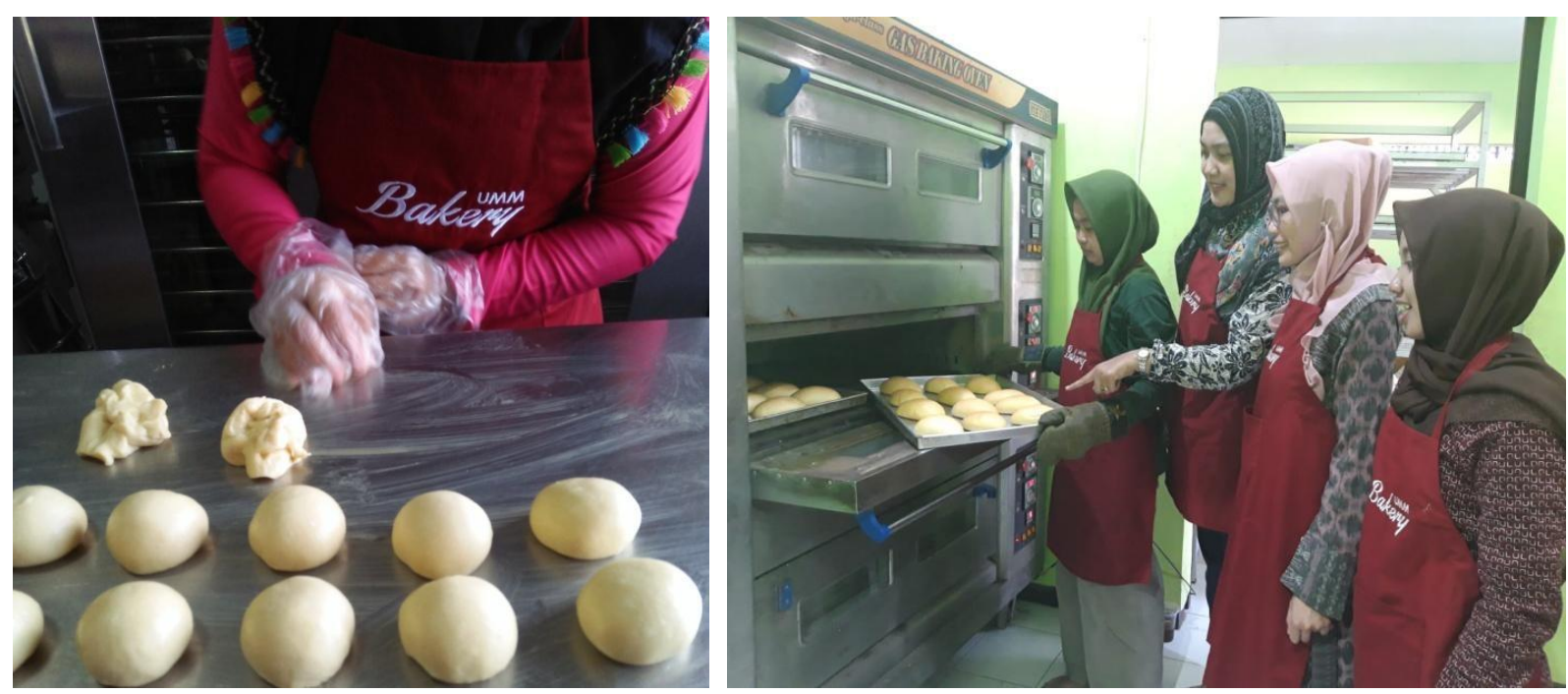

Gambar 3. Pengolahan roti. Ket a. praktik pembuatan proses rounding, b proses pengecekan kualitas roti 


\section{Hasil Evaluasi Pelaksanaan Pengabdian}

Tabel 3. Hasil evaluasi quesioner dengan skala likert sebelum tahap sosialisasi pembuatan roti dengan metode frozen dan sourdough

\begin{tabular}{|c|l|c|c|}
\hline NO & \multicolumn{1}{|c|}{ PERTANYAAN } & NILAI INDEKS & $\begin{array}{c}\text { KETERANGAN } \\
\text { NILAI INDEKS }\end{array}$ \\
\hline 1 & $\begin{array}{l}\text { pembuatan roti metode konvensional } \\
\text { membutuhkan waktu yang panjang }\end{array}$ & 80 & Sangat setuju \\
\hline 2 & $\begin{array}{l}\text { kapasitas produksi yang besar } \\
\text { membutuhkan SDM yang banyak }\end{array}$ & 100 & Sangat setuju \\
\hline 3 & $\begin{array}{l}\text { kapasitas produksi harian perlu } \\
\text { ditingkatkan }\end{array}$ & 86,67 & Sangat setuju \\
\hline 4 & $\begin{array}{l}\text { karyawan sering lembur apabila kapasitas } \\
\text { pesanan melonjak }\end{array}$ & 86,67 & Sangat setuju \\
\hline 5 & $\begin{array}{l}\text { sering menolak pesanan dalam kapasitas yang } \\
\text { besar }\end{array}$ & 80 & Sangat setuju \\
\hline 6 & $\begin{array}{l}\text { ingin cara yang lebih mudah dalam } \\
\text { produksi roti jumlah besar }\end{array}$ & 80 & Sangat setuju \\
\hline 7 & $\begin{array}{l}\text { ingin metode baru dalam pembuatan roti } \\
\text { untuk meningkatkan kapasita produksi }\end{array}$ & 73,33 & Tidak setuju \\
\hline 8 & $\begin{array}{l}\text { mengetahui pembuatan roti metode } \\
\text { frozen }\end{array}$ & 24,44 & Sidak setuju \\
\hline 9 & $\begin{array}{l}\text { mengetahui pembuatan roti metode } \\
\text { sourdough }\end{array}$ \\
\hline 10 & $\begin{array}{l}\text { Ingin menerapkan metode frozen dalam } \\
\text { pembuatan roti }\end{array}$ & 66,67 & Setuju \\
\hline 11 & $\begin{array}{l}\text { Ingin menerapkan metode sourdough } \\
\text { dalam pembuatan roti }\end{array}$ \\
\hline
\end{tabular}

Dari data diatas didapat hasil bahwa mitra membutuhkan inovasi baru untuk membuat roti dalam jumlah besar. Hal ini dikarenakan mitra sering menolak pesanan dalam kapasitas besar akibat kurangnya SDM yang ada dan meningkatnya biaya produksi jika menambah tenaga lembur serta tidak seragamnya kemampuan tenaga lembur. Penerapan metode frozendough mampu mengatasi masalah tersebut karena penyimpanan adonan dalam bentuk beku hanya membutuhkan proses thawing dan pengovenan untuk menjadi produk, sehingga untuk produksi kapasitas besar membutuhkan waktu yang lebih singkat dan tenaga yang lebih sedikit.

Tabel 4. Hasil evaluasi quesioner dengan skala likert setelah tahap sosialisasi pembuatan roti dengan metode frozen dan sourdough

\begin{tabular}{|c|l|c|c|}
\hline NO & \multicolumn{1}{|c|}{ PERTANYAAN } & NILAI INDEKS & $\begin{array}{c}\text { KETERANGAN } \\
\text { NILAI INDEKS }\end{array}$ \\
\hline 1 & $\begin{array}{l}\text { penyampaian program pendampingan } \\
\text { penggunaan metode frozen dan } \\
\text { sourdough mudah dipahami }\end{array}$ & 80 & Sangat setuju \\
\hline 2 & $\begin{array}{l}\text { rtarik untuk menerapkan metode frozen } \\
\text { dan sourdough dalam pembuatan roti }\end{array}$ & 100 & Sangat setuju \\
\hline
\end{tabular}




\begin{tabular}{|c|l|c|c|}
\hline 3 & $\begin{array}{l}\text { metode frozen dan sourdough merupakan } \\
\text { inovasi yang dapat meningkatkan } \\
\text { kapasitas produksi roti }\end{array}$ & 86,67 & Sangat setuju \\
\hline 4 & $\begin{array}{l}\text { bahan pembuatan metode frozen dan } \\
\text { sourdough mudah diperoleh }\end{array}$ & 86,67 & Sangat setuju \\
\hline 5 & $\begin{array}{l}\text { harga bahan metode frozen dan } \\
\text { sourdough terjangkau }\end{array}$ & 80 & Sangat setuju \\
\hline 6 & $\begin{array}{l}\text { metode frozen dan sourdough dapat } \\
\text { memberikan dampak positif } \\
\text { metode frozen dan sourdough dapat } \\
\text { memberikan dampak negatif }\end{array}$ & 80 & Tidak setuju \\
\hline
\end{tabular}

Dari data diatas didapat hasil bahwa setelah adanya pelatihan dengan metode frozen dan sourdough pihak mitra jadi mengetahui metode untuk menerima pesanan dalam kapasitas yang besar.

\section{KESIMPULAN}

Adapun kesimpulan yang dapat diambil yaitu sebagai berikut.

1. Peningkatan pengetahuan karyawan terhadap teknologi pembuatan roti tercermin pada tingkat pemahaman dan ketertarikan terhadap metode frozen dan sourdough dan sebagian karyawan telah mampu mengaplikasikan teknologi ini.

2. Pembuatan roti metode frozendough dan sourdough dapat meningkatkan efisiensi proses produksi sehingga unit usaha terbantu untuk melayani pesanan dalam jumlah besar.

\section{DAFTAR PUSTAKA}

Edema, M.O., Sanni, A.I., 2008. Functional properties of selected starter cultures for sour maize bread. Food Microbiology 25, 616-625.

Hendri, J. (2009). SKALA PENGUKURAN DAN TEKNIK PENSKALAAN. RISET PEMASARAN - UNIVERSITAS GUNADARMA - , 4-6.

Katina, K., Laitila, A., Juvonen, R., Liukkonen, K.-H., Kariluoto, S., Piironen, V., Landberg, R., Aman, P., Poutanen, K., 2007a. Bran fermentation as a means to enhance technological properties and bioactivity of rye. Food Microbiol. 24, 175-186.

Miller, Simon Derek. 2006. Yeast Metabolism in Fresh and Frozen Dough. Thesis. New Zealand: Massey University, Palmerston North.

Moroni, A. V., Dal Bello, F., \& Arendt, E. K. (2009). Sourdough in gluten-free breadmaking: An 423 ancient technology to solve a novel issue? Food Microbiology, 6, 676-684.

Sangjin Ko. 2012. Rahasia Membuat Roti Sehat \& Lezat dengan Ragi Alami. IndonesiaTera

Yi, J. dan William L. K. 2009. Combined Effects of Dough Freezing and StorageConditions on Bread Quality Factors. Journal of Food Engineering 93 :495 -501. 